\title{
Public Freedoms in the Jordanian Constitution: Rhetorics and Realities
}

\section{Khair Bani Doumi M*}

Arab Open University, Jordan

\begin{abstract}
This research addresses the issue of public freedoms in the Jordanian constitution by identifying public freedoms concepts, reviewing the types of public freedoms in the world, and tracing the state of public freedoms in Jordan through constitutional texts and practical application. The study has employed the descriptive, analytical, and legal approaches. The findings revealed several conclusions,. First, the 1952 Constitution, which is currently in force, contains a range of civil and political rights for Jordanian citizens. Second, this Constitution has been reinforced by a series of legislation regulating the exercise of these rights and duties of the state to ensure the enjoyment of them. More importantly, practices on the ground shows a huge difference between theory and the reality of public freedoms in Jordan, specially with regards to media. This requires ensuring that the provisions of the Constitution are highly considered by all authorities to guarantee public freedoms.
\end{abstract}

Keywords: Constitution; Jordan; Public freedoms; Human rights

\section{Introduction}

The concepts of public freedoms began to emerge in the seventeenth century in the western part of the European continent, and they were widely used in the eighteenth and nineteenth centuries. The following decades and years saw great interest in public freedoms. They were referred to in the American and French declarations, or constitutions, as an essential part of human rights, as well as the establishment of national and international institutions concerned with public freedoms. In the twentieth century, public freedoms and related concepts and institutions became the motto of the stage. Public freedoms have evolved so much that the way the state treats its citizens is no longer an internal matter of the state alone. Based on the traditional understanding of the concept of national sovereignty that prevailed until the middle of the last century, public freedoms became a global affair for the entire international community, as these freedoms are an integral part of human rights, a prerequisite for human development, and a cornerstone of democracy as there is a close link between public freedoms and democracy.

In the Arab world, popular and official interest in public freedoms began after the second half of the twentieth century. The Arab constitutions that emerged during that period reflected the concern for public freedoms. Many Arab constitutions stipulated respect for public freedoms [1]. The popular interest in public freedoms in Jordan has appeared since the beginning of the Jordanian state. Popular demands and movements reflect this concern. However, the Jordanian constitutions of 1928 and 1946 did not clearly state the concepts public freedoms freedoms. While the Constitution that was passed in 1952, that is still valid today, came ahead of the previous constitutions, and included directly and explicitly the concepts of public freedoms in its texts. The Constitution is considered the supreme law of the state, which defines the relationship between the state and the citizens, thus constitutes the guarantee of the protection and respect public freedoms. However, the reality of the situation in Jordan reveals a huge gap between theoretical rhetorics and practices.

This study aims at identifying public freedoms in the Jordanian constitution, especially in the 1952 Constitution that is currently in force, and the reality of these freedoms in terms of actual practice and practical application. The real practice on ground is the measure in governance, regardless of constitutional texts or legal legislations. The importance of this study stems from the absence of clear scientific studies on the relationship between the constitution and public freedoms. This topic touches on the ambiguity and multiple interpretations of the nature of this relationship. Among those who see the absence of the relationship between the constitution and public freedoms, on the basis that the significance lies in the actual pratice on ground. This is why we believe that there is a close relationship between the provisions of the Constitution and public freedoms. This study seeks to answer the following main question: What is the reality of public freedoms in Jordan, in light of the constitutional texts and practices? And the minor research questions are summarized as follows:

- What are public freedom concepts and how have they evolved over time?

- Are constitutional provisions sufficient to provide an enabling and encouraging environment to ensure respect public freedoms?

- What is the reality of public freedoms in Jordan in light of the reports of national and international human rights organizations?

This study comes to explore the status public freedoms in the Jordanian constitutions, especially in the 1952 Constitution that is currently in force, and the reality of these freedoms in terms of actual practice and practical application. The practice on ground is the measure in governance regardless of constitutional texts or legal legislation.

\section{Types of public freedoms}

There is a long list of basic rights and freedoms enshrined in the declarations, constitutions, and ordinary legislations issued in various countries of the world. First, there are the traditional public freedoms in which states refrain from being exposed to individuals as long as they represent legal centers through which individuals exercise their own characteristics in order to satisfy their own needs. These freedoms are

*Corresponding author: Khair Bani Doumi M, Arab Open University, Jordan, Tel: +962 6563 0630; E-mail: drbanidoumi@hotmail.com

Received May 09, 2018; Accepted August 09, 2018; Published August 16, 2018

Citation: Doumi MKB (2018) Public Freedoms in the Jordanian Constitution: Rhetorics and Realities. J Mass Communicat Journalism 8: 384 . doi: 10.4172/2165-7912.1000384

Copyright: (c) 2018 Doumi MKB. This is an open-access article distributed under the terms of the Creative Commons Attribution License, which permits unrestricted use, distribution, and reproduction in any medium, provided the original author and source are credited. 
basically the list of citizens' rights in the constitutions and declarations of rights that began to appear since the late 18th century. On the other hand, there are economic and social freedoms, where the state does not stand in the face of these freedoms. This is a group of freedoms that have become prominent in the list of public freedoms since the end of the First World War because of the evolution of the idea of freedom from being just an idea aimed at breaking the barriers to an idea that promotes the development of human dignity; all because of the interdependence between the idea of political democracy and social and economic democracy [2].

In general, public freedoms can be divided into two main parts:

- Civil and political freedoms.

- Intellectual freedoms

- Economic, social and cultural freedoms

A quick review of these freedoms follows:

1. Civil and Political Freedoms:These include:

- $\quad$ Freedom of housing

- Freedom of communication and correspondence Freedom of movement.

2. Intellectual freedoms include:

- $\quad$ Freedom of belief and religion

- Freedom of opinion

- Freedom of assembly and association.

3. Economic, social, and cultural freedoms:

- $\quad$ Freedom of learning

- $\quad$ Freedom of labor

- $\quad$ Freedom of trade and industry

- Freedom of Ownership.

\section{Guarantees of the exercise of public freedoms}

The public freedoms that were highlighted earlier may become mere ink on paper without the existence of guarantees that allow the implementation, and protection of these freedoms. There are several guarantees for practicing public freedoms; the most important are:

- First: The existence of a constitution for the state: The existence of a constitution that includes the rights and freedoms is the first guarantee for the maintenance and protection of these freedoms and establishing the legal system within the state. The Constitution explains the system of government in the state and indicates the status of public authorities and how they exercise these powers and the limits of their respective jurisdictions. The constitutional texts on the rights and freedoms of individuals are restrictions on the authority of the state.

- Second: Separation of powers: In the sense that there is a separation between the three authorities in the state: the legislative, executive, and judicial authorities, then there is a branch that is in charge of matters of legislation, one that is in charge of matters of implementation, and another that is in charge of judiciary matters. If this happens, each side has its specific competence, which cannot be overridden.
- Third: The principle of the incorporation of legal rules: It is established that the rules in the legal system of the state are not in a single rank in terms of their strength and legal value. These rules are ranked so that some of them are higher and stronger than others. This requires that the rule be subordinated to form and substance. Thus making the constitution at the top of these laws.

- Fourth: the supervision of the constitutionality of laws: they are carried out by political supervision or judicial control, each working to ascertain the compatibility of legislative and executive work with the provisions and principles of the Constitution, as the lack of conformity means the abolition of the law did not match the provisions of the Constitution.

- Fifth: Judicial control over the work of the administration: It shall be through the control of a judicial body or the socalled administrative judiciary, which monitors the work of the administration and the extent of their conformity with the law [3].

\section{Literature Review}

Despite the paucity of previous studies that dealt with the relationship between the Constitution and public freedoms in Jordan directly or indirectly, there are a number of studies that tried to approach the content and objectives of this study. Azzam [4] conucted a study aiming to identify the state of public freedoms in the constitutions of the Arab countries, based on the tragic situation of public freedoms in the Arab world. Public freedoms in the Arab world are in a deplorable state, where strict control of freedom of opinion and expression and assembly. The Arab states follow the system of the modern state in terms of form and organization, but do not translate the values of the modern state governed by the law or the rule of law in their constitutions, which regulate the relationship of individuals with the state and authority. The study shows that the guarantees of respect for public freedoms in the Arab countries are not applied, despite the inclusion of provisions regarding public freedoms within Arab constitutions.

In another study, Bani Salameh and Samid [5] aimed to address the issue of public freedoms in the Arab world on three levels:

- $\quad$ First: the level of official Arab and Islamic discourse, ie in the Arab and Islamic countries, and the speeches of events and the language of the media.

- Second: the relationship between the state, the people, and these freedoms.

\section{- $\quad$ Third: practical practices.}

On the level of public freedoms in the official discourse, the study considers that all Arab regimes try to claim that they are democratic, respect public freedoms fully, and prevent violating them by all means. Those who read the texts of the constitutions believe that the Arab countries are democratic states, and this is incorrect and unreal.

On the level of public freedoms in the state's relations with the people and international texts, the study shows that the Arab state is not enthusiastic about joining the international covenants and conventions related to the general freedoms, based on excuses and false arguments.

On the level of public freedoms in practice, the study considers that practice on the ground is the main criterion in judging any system, regardless of the provisions of the constitutions. The study considers that the state of public freedoms in the Arab world, as documented by the reports of organizations concerned with public freedoms, indicate that respect for public freedoms is not one of the priorities 
of Arab political systems. Moreover, Mohammed and Salameh [6] have investigated the reality of rights and freedoms in Jordan and the constitutional violations and temporary laws that were introduced, presented, and contradicted in many cases. It also tackled the power of the executive branch over the legislative power, and the weakness and inability of the representative parliament to block this change. The author highlighted the conditions of issuing provisional laws in the constitutions of the parliamentary system and the conditions of their issuance in the Jordanian constitution. He referred to the provisional laws issued by the government within 21 months when the 13th parliament was dissolved, and reached 160 laws that violated the legal system in Jordan. As well as the Political Parties Law No. 19 of 2007 from the perspective of constitutional freedoms, and the author described it as a punitive law that distinguishes between Jordanians and penalizes union leaders as well, and how the new law gave the government complete power over the parties' finances. The writer touched on the subject of political development and the supposed supervisory role of the House of Representatives, in light of the reality in Jordan, to protect the constitutional rights and freedoms, which must be the first step for reform. More importantly, Hiyari [7] conducted another study to identify the impact of the Arab Spring on the economically prosperous and, to some extent, politically stable countries in the Gulf, and how the Gulf states dealt with the so called the Arab Spring. Are these countries immune to the winds of change that have afflicted the region? How have these changes affected the security and balance of power in the Arabian Gulf? Have they made the Gulf safer or less? The Gulf states always claim that they are not interested in the winds of change, that they have immunity against the democratic reform movement, and that it is an exceptional situation in the Arab world.

The study concluded that the GCC countries are part of the Arab regional system and that they will inevitably be affected by what is happening in the regional environment, and perhaps what happened in Bahrain is the best proof of this. The Arabian Gulf is part of its Arab environment, and it has one destiny and one future; when the moment of freedom arrives to the Arab region, it'll also arrive to the Gulf. There is no Arab state that has immunity, regardless of its wealth. The Arab land demands freedom from the Arabian Gulf to the Arab Maghreb, and the Arab peoples, including the Gulf region, are yearning for freedom, participation, democracy, and access to their civil and political rights in full and undiminished, and they deserve political and constitutional reform sooner rather than later. However, Satloff [8] in his study attempted to identify human rights in Jordanian constitutions through a quick review of the development of human rights concepts in the world and the journey of the development of Jordanian constitutions. The results of the study showed that the Jordanian constitutions issued in 1928 and 1946 did not contain concepts of human rights as required, nor did they reflect the will of Jordanians looking for political participation and fundamental freedoms. The 1952 Constitution, which is currently in force, contains a range of civil and political rights for Jordanian citizens. This has been reinforced by a series of legislation regulating the exercise of these rights and duties of the state to ensure the enjoyment of them. However, in practice there is a huge difference between theoretical texts and the reality of human rights in Jordan. This requires ensuring that the provisions of the Constitution are respected by all authorities as the surest guarantee of respect for human rights. Bani Salameh, in another study, Al-Youm [9] attmpted to identify the concept of political reform-its mechanisms and its motives in Jordan - and to review its status under the reign of King Hussein and
King Abdullah II. The study also aimed to identify obstacles to political reform in Jordan and to present a road map that outlines the desired political reform in the country.

A main finding of this study is that political reform in Jordan is an old and popular demand, and that the process of political reform in the country has made some achievements but that it has not been enough to push for real and profound reforms. There is much talk about reform, but the actual practice of reform points to stagnation and regression in the process. The study presented a number of recommendations, most notably: the need for further constitutional amendments in order to consolidate the democratic principle of "sovereignty of the people," reduce the executive authority's access to other authorities, and reconsider the laws governing political life, in order to build a state ruled bylaw and institutions and to establish a society of justice and equality and overcome the Arab Spring.

\section{The Jordanian Constitution of 1952}

The constitution of 1952 came in response to internal and regional circumstances and developments, including the absence of prince Abdullah I from the political scene, and the assumption of power by the young King Talal, with national and democratic tendencies, as well as the unity of the two banks of Jordanian river in 1950 and the popular movements in the country calling for reform and democracy These conditions were the means that led to the adoption of a new constitution in the country, which came ahead of the constitutions that were issued before. Where it states that the nation is the source of authority, and this democratic principle did not exist in previous constitutions; it also took the democratic principle of linking responsibility to accountability, and made the government accountable to parliament [10]. This Constitution came fully organized with clear and accurate rights and freedoms along with the safeguards and guarantees governing the exercise of these rights, which were based on the importance of the democratic principle of equality.

In the early years of this constitution, Jordanians experienced a pioneering democratic experiment. Elections were conducted freely and impartially. The Parliament exercised its role of full supervision and legislation. Party life flourished, and the press enjoyed a significant amount of freedom. However, this process quickly stopped, and research into details and reasons goes beyond the scope of this article.

The constitution was then subjected to a series of amendments and lost many of its democratic principles; thus, some view this as a coup against the constitution [11]. Where martial law was imposed, the democratic process was completely halted from 1957 to 1989 . When Jordan resumed democracy in 1989 , no amendments were made to the constitution to restore the lost balance and the democratic principles on which it was based. The constitutionkept on working, which made the democratic experience in the country fragile, and sometimes there was a decline as a result of regional and international developments and events.

\section{Constitutional amendments under King Abdullah II}

In the framework of the political reform process pursued by the Jordanian political regime under the reign of King Abdullah II Ibn alHussein, and in response to the increasing pressure and popular demands for genuine political reform in the country, the constitutional amendments to the Jordanian constitution under King Abdullah II were at the top of the list of desired political reforms in the country, due to the supremacy of the constitution as the master law that outlines the political, economic 
and social life in the country and establishes the rules on which the regime stands and operates. The sought political reform and the democratic transition that Jordan seeks to achieve stem primarily from the constitution. It is the first link in the reform process. It is not possible to bring about real political reform in Jordan under the constitutional provisions that give the executive authority wide powers, such as dissolving the parliament, as well as the authority to issue laws and other powers, according to the Jordanian Constitution.

In 2009, the popular movement in Jordan began with economic demands, such as the mobility of port workers, workers in the Ministry of Agriculture, the teachers demanding the establishment of a professional union, and the mobility of military retirees. This popular mobilization was preceded by the beginning of the so-called Arab Spring, which started in Tunisia in 2010. The political regime's response to these demands was cold and hesitant. The revolutions of the Arab Spring, however, and the fall of the political regimes in Tunisia, Libya, and Egypt led to the mobilization of the Jordanian street. Calls were launched throughout the country demanding fundamental reforms of the political regime. This has led the political regime to take several reform steps to relieve popular tensions without prejudice to the privileges of power centers and the focal points of corruption, including the establishment of the National Dialogue Committee, formed from the various parts of the country's political spectrum. It made recommendations, including constitutional amendments and the adoption of a modern electoral law leading to the formation of a parliamentary government, and the enacting of the law of parties enriching multi-party elections, believing the election laws and parties to be the most important laws, which regulate political action and are the gateway to comprehensive political reform [12].

Accordingly, King Abdullah II formed a royal committee to review the constitution and recommend necessary constitutional amendments to achieve the desired political reform and the development of political life in the country. Forty-two total constitutional amendments were submitted to the Constitution, amounting to about one-third of the existing articles of the Constitution (131). In this context, we will review the most important constitutional amendments .

\section{Constitutional Amendments}

The most important aspects of constitutional amendments, which were based on the recommendations of the Royal Commission to achieve political reform and promote the democratic process in the country, are as follows:

\section{Rights and freedom:}

The amendments to the Constitution with regard to the rights and freedoms set out in Chapter II of the Constitution are articles $6,7,8,9,15,16,17,18$ and 20 [13], which have added positively to the status of those rights and freedoms. These articles considered the violation of public rights and freedoms an offense punishable by law, stressed the inadmissibility of arresting or restricting the freedom of the citizen except in accordance with the provisions of the law, affirmed the unconstitutionality of torture and physical or moral abuse, and stressed the privacy of the right of Jordanian citizens through the prohibition of the monitoring of any postal, telegraphic, telephone, or other communications except by judicial order, in accordance with the provisions of the law. It has affirmed the freedom of opinion, thought, and expression. It is no longer permissible to suspend newspapers or the media or to revoke their licenses except by judicial order in accordance with the provisions of the law.

\section{Royal powers}

In the first section of the fourth quarter, under the executive title, which deals with the king and his rights in articles 28-40,there have been no changes to the Constitution, where it kept materials to be deleted, and refrained from modifying the materials to be adjusted; it is surprising that the new constitutional amendments not only did not affect the constitutional provisions regarding the rights of the king but also added a new article giving the king the right to appoint the president and members of the Constitutional Court. In 2014, new constitutional amendments granted the king exclusive powers to appoint the army commander and the Director of General Intelligence Department without the recommendation by any party. Those amendments have been justified with the reasoning that the aim is to keep these positions safe from any polarization or political bickering and to keep military institutions and public intelligence independent, impartial, professional, and non-politicized [14].

Reformists in Jordan believe that these amendments made the government devoid of actual powers and contradicted the principle of the general mandate of the Council of Ministers in accordance with Article 45 of the Constitution, which states: "The Council of Ministers shall administer all internal and external affairs of the State". This group goes so far as to say that these amendments have transformed the royal monarchy in Jordan into a presidential system, hampering reform efforts and seeking to establish parliamentary governments [15]. In 2016, a new constitutional amendment was introduced whereby the authority to appoint the Gendarmerie Commander to the King was added to enhance the neutrality of the Gendarmerie and to protect it from political influence whereas many advocates of political reform in the country believe that its survival without amendments is a derogation from an indivisible democracy and an amnesty for the principle that the people are the source of authority [16].

\section{Executive Authority}

Fundamental amendments have affected the executive authority with regard to its composition, functions, ministerial statements, and responsibility before Parliament. A positive and substantial amendment was made to Article 53. Each government is now required to submit its ministerial statement to Parliament if it is in session and requests confidence in that statement; if Parliament was not scheduled to convene for a special session, the ministry should submit its ministerial statement and request confidence in that statement. If Parliament is dissolved, the government should submit its ministerial statement and request confidence in that statement from the new Parliament. This amendment canceled the speech of the throne, which was formed by the government in the absence of the Parliament and considered a ministerial statement that governments hide behind in order to obtain the confidence of the Parliament, and thus affect the voting behavior of the members of the Parliament in granting confidence to the government, as MPs are reluctant to criticize the speech of the king. The government has issued a ministerial statement, and the deputies rarely give a vote of no confidence to a government that presents the speech of the throne as a ministerial statement.

Among the important amendments to the Constitution and the executive authority is the establishment of an independent body supervising the electoral process under the provisions of Article 67, which means the end of the hegemony of the executive authority by holding the elections in all stages, from organizing the registration process to supervising the voter lists, managing the electoral process, 
supervising the voting process, counting votes, and announcing results. In this context, practical experience indicates blatant interference by the executive branch in the electoral process and tampering with the will of the voters to rigorously falsify the elections [17]. The introduction of an independent institution to oversee elections is important, as it can contribute to a rebalancing of legislative and executive power and restore the legislative power, especially if the body is able to play its role optimally under a democratic election law.

\section{Legislature}

The constitutional amendments included a number of texts that restore the balance between the legislative and executive branches by amending certain provisions that established the hegemony of the executive power over the legislative authority, the foremost of which is the dissolution of the parliament and the indefinite postponement of elections. The executive branch is not arbitrarily disbanded. Under Article 74 of the constitution, the government that dissolves Parliament will resign during its term of office within one week of the date of dissolution. It is not permissible to assign its president to form the next government. This amendment represents a return to the previous text of the 1952 constitution before it was amended. The government is considered a guarantee to rein in the executive authority. The constitutional amendments also revoked paragraphs 4, 5 and 6 of Article 73 of the constitution, which gave the king the power to defer elections indefinitely if there were emergency circumstances in which the Council of Ministers deemed it impossible to conduct the election.

Among the important amendments relevant to the legislative authority is the limitation of the power to hear parliamentary appeals by justice, so that each voter has the right to submit an appeal to the Court of Appeal in his or her constituency about the MP's rightness of his or her mandate in his or her constituency within fifteen days from the date of publication of the election results in the Official Gazette. The Court's decisions are final and not subject to appeal, under the amendment of the Article 71, whereas in the past Parliament could decide on the validity of its members, and often exercised this authority with bias in favor of its members, where it acted both as opponent and referee. This matter of deciding the rightness of membership in Parliament has been handed to the judiciary in order to achieve justice.

\section{Judiciary}

The new constitutional amendments included a number of texts that enhance the independence of the judiciary. The word "independent" was added to Article 27 of the Constitution to read: "The judiciary is independent and is governed by courts of all types and degrees." As well as to strengthen its role in guaranteeing and protecting the rights and freedoms of individuals so that laws and legislation issued by the Constitution do not infringe upon the essence of these rights, the most important amendments are the amendment of Article 98 of the Constitution, stating that the judiciary will have the right to appoint, promote, transfer and dismiss judges, etc., which will guarantee the judiciary financial and administrative independence from the executive branch. All matters relating to the appointment, promotion, transfer, assignment, and retirement of judges have become the sole domain of the Judicial Council without interference from the executive branch.

Among the amendments related to the judiciary are the establishment of the Constitutional Court in accordance with Articles 58, 59, 60, and 61 of the constitution. Its main task is to monitor the constitutionality of laws and regulations issued by the executive branch and to have the final say on the interpretation of the constitution. This demand dates back to 1990, when issuing the National Charter, which provided for the establishment of a constitutional court to adjudicate the cases referred to it by the courts of constitutional issues, and the dismissal of appeals relating to the constitutionality of laws and regulations. In fact, the Constitutional Court is one of the pillars of democracy in the state, a fact recognized by all legislations in Arab and foreign countries [18].

\section{Public freedoms in the current 1952 Constitution}

It can be said that the constitution of 1952 is among the rich constitutions in texts related to human rights and fundamental freedoms. This constitution consists of 10 chapters and 131 articles. However, The articles related to human rights in the Constitution of Jordan Including amendments of May 2016 are the following

\section{Article 7}

(1) Personal freedom shall be guaranteed.

(2) Any infringement on the rights and public freedoms or sanctity of private life of Jordanians is a crime punishable by law.

\section{Article 8}

(1) No person may be arrested, detained, imprisoned, have his/ her freedom restricted or prevented from free movement except in accordance with the provisions of the law.

(2) Every person who is arrested, imprisoned or whose freedom is restricted, must be treated in a way that preserves his/her human dignity. It is forbidden for him/her to be tortured (in any form) or harmed physically or mentally, as it is forbidden to detain him/her in places outside of those designated by the laws. Any statement extracted from a person under duress of anything of the above or the threat thereof shall neither bare any consideration nor reliability.

\section{Article 14}

The State shall safeguard the free exercise of all forms of worship and religious rites in accordance with the customs observed in the Kingdom, unless such is inconsistent with public order or morality.

\section{Article 15}

(1) The State shall guarantee freedom of opinion. Every Jordanian shall be free to express his opinion by speech, in writing, or by means of photographic representation and other forms of expression, provided that such does not violate the law.

(2) The State shall guarantee freedom of scientific research. It shall also guarantee the freedom of literary, artistic and cultural creativity if not contrary to public order and public morals.

(3) Freedom of the press, publications and mass media shall be ensured within the limits of the law.

(4) Newspapers shall not be suspended from publication nor shall their permits be revoked except by a judicial order in accordance with the provisions of the law.

(5) In the event of the declaration of martial law or a state of emergency, a limited censorship on newspapers, publications, books, broadcasts and other means of communication in matters affecting public safety and national defense may be imposed by law.

(6) Control of the resources of newspaper shall be regulated by law. 


\section{Article 16}

(1) Jordanians shall have the right to hold meetings within the limits of the law.

(2) Jordanians are entitled to establish societies, associations and political parties provided that the objects of such societies and parties are lawful, their methods peaceful, and their by-laws not contrary to the provisions of the Constitution.

(3) The establishment of societies, associations and political parties and the control of their resources shall be regulated by law.

\section{Article 87}

Every Senator or Deputy shall have complete freedom of speech and expression of opinion within the limits of the Internal Regulations of the Senate or Chamber of Deputies, as the case may be, and shall not be answerable in respect of any vote which he had cast or opinion expressed or speech made by him during the meetings of the House.

\section{Article 128}

\section{Substance of rights and freedoms, legal continuity}

(1) The laws issued by virtue of this Constitution to regulate the rights and freedoms shall not impair the substance of these rights or affect their fundamentals.

\section{The reality of public freedoms in Jordan}

Article (7) of the constitution relating to personal freedom, which came in the constitution consistent with international human rights standards that ensured the human right to freedom. In reality in Jordan, despite the constitutional guarantees of this right, the national legislation - especially the Code of Criminal Procedure is still insufficient to achieve the required protection of the human right in freedom. There are many practices that constitute a violation of this right, such as the administrative authorities and the arrest of persons deprived of their liberty under administrative decisions, and interrogated without the presence of complaints against them on the basis of the Crime Prevention Act; the National Center for human rights recommended in many annual reports to rescind it immediately, because it constitutes a clear violation of international and national standards, and arbitrariness by members of the judicial authority, where the person is punished twice for one act; once through the judiciary, and again by the administrative rulers .

As for article 8, the application of this article is still flawed in the legislative environment, coupled with policies and some misconduct of the executive authorities. The National Center for Human Rights has published its reports to the public, documenting the torture and ill-treatment of prisoners by the departments responsible for the care, rehabilitation, and protection of prisoners, and the continuing impunity of the perpetrators of these crimes, which means that there are violations by these authorities of international standards contained in international conventions against torture and other forms of illtreatment. The successive governments have formed committees to deal with this phenomenon. In this regard, it is worth to note the improvement in the conditions of prisoners in the country. A national register of torture cases has been established and the prosecution has begun investigating some cases of torture.

The application of Article (15), as well as the laws issued in relation to it, failed to meet the provisions of the article, which can be considered very advanced if it is exempted from the exceptions contained in it, such as stipulations that do not exceed the limits of the law and according to the provisions of the law, those are loose or ambiguous sentences, and subject to multiple interpretations which may eventually lead to the emptying of the constitutional article of its content. In accordance with international law, if the State has discretion in determining the circumstances and freedoms to limit its enjoyment and exercise, such restrictions must be set forth in the law in a precise, specific, and detailed manner so as not to leave things in a clouded position. The Authority uses these situations to restrict the essence of this right.

The freedom of expression is the basic and primary expression of intellectual freedoms. The International Covenant on Civil and Political Rights (ICCPR), of 1966, is clearly stated in Article (19) of the Constitution, the protection of this right is one of the most important pillars of the protection of human rights and the promotion of democracy.

The reality of the situation in Jordan confirms that freedom of expression is limited in practice. The vast majority of citizens exercise self-censorship consistent with the guidelines of official policy, and all official media convey only one viewpoint. The limited expression and the increasing restrictions on it are reflected in the arsenal of laws governing opinion and expression issues such as the law of public meetings, the law of the State Security Court, the Penal Code, etc., as well as the high number of arrest cases, the arrest of journalists and citizens and their transfer to the State Security Court on issues relating to freedom of opinion and expression, and restricting the publication of some articles in the daily newspapers by its administrations, and forcing its authors to publish them on websites, and to intimidate journalists, bloggers and users of the Internet, because of their views, contrary to the previous article, as well as international standards of human rights. This is confirmed by many reports of human rights organizations that confirm Jordan's decline in the index of freedoms in the past years. While Jordanian authorities justify the repressive practices of freedom of opinion to maintain security and stability in the country in a turbulent regional environment; observers believe that these practices aim to weaken the opposition, and dry the sources of protest and criticism.

With respect to Article 16, the right to peaceful assembly is one of the basic rights guaranteed by international charters. In Jordan, the Public Meetings Law regulating this right prevents the holding of meetings without the prior approval of the administrative governor. The law has restricted the right of assembly, hindered freedom of expression, and the right to political participation contrary to the provisions of the Constitution. As a result of this law, the authorities have prevented many meetings, rallies, dialogues, and symposia. Many sit-ins and peaceful demonstrations, demanding political reforms, have been dissolved with force, and hundreds of activists have been jailed for being involved in activities that have not been approved by the administrative governor.

This applies to the laws of charities, social organizations, trade unions, and other civil society organizations. For example, applications for registration of new associations are forwarded to the Ministry of Interior, which in turn sends applications for registration of new associations to the General Intelligence Department (GID), which may recommend accepting or rejecting the application. The government dissolved several associations on the pretext of committing legal offenses. In addition, restrictions on the work of associations complicate the procedures for obtaining funding from international donors, resulting in loss of access to finance. 
As for political parties, there are many practices that restrict party work and participation in political and public activities, and the lack of openness of state institutions to parties and their involvement in managing public affairs, which led to the reluctance of the majority of citizens to join them. Despite the amendment of the law of parties to become the reference authority for the licensing of political parties by the Ministry of Political Development instead of the Ministry of Interior, but consulting the opinion of the General Intelligence Department is still the determinant in the licensing of political parties; the license of more than one political party has been rejected based on this fact.

Despite the fact that the Political Parties Law does not permit exposure to the citizen, accountability, or infringement of his constitutional rights because of his party affiliation, the National Center for Human Rights registered complaints against the General Intelligence Department intervention to prevent a number of members of opposition parties from being appointed to government jobs, official universities, and private companies. In general, it can be said that the security establishment still controls all aspects of life in the country, and uses the policy of iron fist in dealing with the opposition or advocates of reform.

With respect to article 17 concerning the right to address public authorities, the application of this article is still out of reach. Public authorities receive tens of thousands appeals of citizens in personal or public matters. However, it is not possible to know the response of the authorities to the content of these communications. The practical reality reveals that there is no guarantee of the implementation of this right.

Concerning article 18, there are no real restrictions on the freedom of correspondence and telephone calls. Despite the recent amendments to the Constitution, the constitutional text has not been subjected to electronic communications, which have become the most widely used means of communication in which freedom is violated, especially in social networking sites, as many politicians complain, including former senior officials of wiretapping their phone calls and other private correspondence.

Finally, we find in the text of Article (128) a very fine content that it is not permissible for any law to regulate the rights and liberties to negatively affect the essence of these rights. The legislator is required to make the laws, not restrict the rights and freedoms but rather regulate and protect them.

There is no doubt that respect for human dignity, fundamental rights, and freedom, and the promotion of a democratic approach in the country are the first steps towards the establishment of a society of justice and equality, the establishment of a state of law and institutions, the achievement of sustainable development, and the maintenance of security and stability.

\section{Media and Constitution}

Freedom of speech is essential for democracy and a guarantor of societal development. The public has the right to access official documents and information held by the public authorities, where the public and journalists in this way can examine power structures and elected politicians. For example, Sweden celebrated 250 years of freedom of the press which has served Sweden well. This is in contrary to what is dominating in the Middle East, where freedom of expression is on decline. However, when it comes to media freedom, Jordan is at the forefront. It is the first in the Middle East to adopt a law on the right to access information, where the Constitution includes guarantees for freedom of expression and of the media.

Nevertheless, although Jordan's national plan for human rights grants journalists sufficient protection while performing their work, and there should be a control on the violations of the freedom of opinion, Jordanian authorities continue to pursue journalists and media workers for "crimes" related to the expression of opinion or the work of the journalist. This is despite the right of "freedom of expression" guaranteed by the Jordanian Constitution in, and despite the International Covenant on Civil and Political Rights, which protects the right to freedom of expression. Therefore, the constitution shall include freedom to seek, receive and impart information and ideas of all kinds, regardless being oral, in writing or in print, in the form of art, or through any other media of his choice. In fact International law does not allow restrictions on these rights, except for narrowly defined restrictions that are consistent with the law and which are necessary in a democratic society to protect national security, public safety, public order, the protection of morals, public health or the protection of others' rights and freedoms.

Indeed, the Jordanian authorities seem to violate these laws without any explanation. An example of this is the the arrest of the Jordanian journalist "Khaled Da'oum" who works as a documentary filmmaker and a researcher at "Taif" Productions and Al Jazeera T.V after his recent trip to Turkey( citing the "Jordan News Network", quoted from Khaled's friend). Another example, from the same source, the journalist Abdel Aziz Abu Bakr narrates his story when the Jordanian police forces (Aldarak) attacked him while performing his journalistic work alongside his colleague Khalid Sadaqa while covering a sit-in near the Israeli embassy in Amman.. Abu Bakr commented on this issue and said: “' The government's handling of many issues related to the status of the press in Jordan raises questions about the decline in the trend of press freedom, considering that it is among the most critical countries with regard to press freedoms according to the index prepared by "Reporters Without Borders".

And in "Sanad" report which issued by "The Network of Defenders of the Freedom of Information Media in the Arab World" for the month of October. It recorded five cases of violation and pressure on five journalists and an electronic news sites. Moreover, the report added that on October 26, the Jordanian Media Commission has prohibited daily and weekly newspapers from broadcasting, publishing or circulating any news or information related to the affairs of the armed forces and their affiliates, except with a direct and explicit request from the responsible sources in the General Command. In addition, it is prohibited to accept broadcasting or publishing any articles or comments except in the scope of Information and news published lawfully and without prejudice to or exposure to the prestige and reputation of the armed forces and their affiliates in any form (direct or indirect). The report, citing the lawyer, "Khalid Khalifat" stated that this is a clear violation of the freedom of opinion and expression, which is contrary to Article 19 of the International Covenant on Civil and Political Rights, Article 15 of the Jordanian Constitution and Article 8 of the Press and Publications Law, which grants the right to the public to know and the circulation of news and information.

\section{Conclusion}

At the end of this study, it can be concluded that there was an early awareness among the Jordanian society of the importance of public freedoms, foremost of which is freedom to participate in the 
Citation: Doumi MKB (2018) Public Freedoms in the Jordanian Constitution: Rhetorics and Realities. J Mass Communicat Journalism 8: 384 . doi: 10.4172/2165-7912.1000384

Page 8 of 8

management of the country's affairs and the freedom of opinion, expression, assembly, and organization.

It is noted in this Constitution that there is no shortage of provisions in the Constitution that emphasize public freedoms. Many of these freedoms are in line with international human rights standards, but they remain as theoretical texts. The reality of practice differs completely from the theoretical texts, full of values and principles of human rights. The imbalance that Jordan suffers is in practice, and therefore it is necessary to end the contradiction between the constitutional texts and the practical translation of them.

This turbulent reality is manifested in several forms, most notably the lack of respect for the provisions of the Constitution, especially in light of the national legislation that contravenes the international conventions and agreements ratified by Jordan, resulting in the violation of many fundamental freedoms. The imbalance that Jordan suffers is in practice more than the constitutional texts.

The other type of disorder is the exception to the constitutional provisions relating to public freedoms, which empties the texts of their value and leads to a violation of the Constitution by making exceptions to the rule. This is reflected in many articles such as freedom of movement (except in cases established by law), and freedom of opinion (within the limits of the law), freedom of the press (within the limits of the law), secrecy of correspondence (in accordance with the provisions of the law), the right to meet (within the limits of the law) and other articles that have emptied the constitutional article of its content.

In conclusion, it must be emphasized that respect for the texts of the provisions of the Constitution by all authorities is the main entrance to respect for human rights and public freedoms, particularly Article 128 of the Constitution, which came to confirm the inadmissibility of the amendment of freedoms and rights only to the extent that they are designed to give more laws, rights, and guarantees for the benefit of the citizen, and when this logic prevails, the situation will change for the better, human rights and freedoms are safeguarded, harmony and justice predominates community, security and stability of the ruler and the ruled alike.

\section{References}

1. Bani Salameh MT, Ali Ananzah A (2015) Constitutional Reforms in Jordan: A Critical Analysis. Digest of Middle East Studies 24: 139-160.

2. Radhi ML, Abdul Hadi HA (2007) Introduction to the Study of Public Liberties. 147-150.

3. Shawi MA (2006) The General Theory of Constitutional Law, (In Arabic). Dar Ward Publishing and Distribution, Amman 302-305.

4. Azzam FS (1995) Guarantees of Civil and Political Rights in Arab Constitutions: Comparative Study. Cairo Center for Public freedoms Studies.

5. Bani Salameh MT, Samid A (2018) Darawsheh, Human Rights in the Jordanian Constitution: Between theoretical texts and practical application. International Journal of Human Rights and Constitutional Studies.

6. Mohammed T, Salameh B (2018) Political Reform in Jordan: Reality and Aspirations. World Affairs Journal 4

7. Hiyari (2018) Constitutional Law and the Jordanian Constitutional System. Ibid 587.

8. Satloff RB (1994) Jordan in Transition: From Abdullah to Hussein. Oxford University Press

9. Al-Youm AA (2011) Report of the National Committee for National Dialogue.

10. (1992) The Constitution of the Hashemite Kingdom of Jordan. Arab Law Quarterly 272-289.

11. Salameh MB, El-Edwan k (2016) The Identity Crisis in Jordan: historical pathway and contemporary debates. Nationality Papers 985-1002.

12. Nassraween LK (2016) The Effect of the Constitutional Amendments in 2014 on the Constitutional System in Jordan. Studies in Sharia and Law Sciences.

13. Hammouri MA (2011) Study in Amendments proposed by the Royal Commission for the revision of the Constitution. Al-Arab Al-Youm 12.

14. Jazeera Al (2014) Jordan prisoners protest sinhumanes treatment

15. Alwan MY, Al-Mousa MK (2009) International Law on Human Rights - Protected Rights. Amman 82.

16. https://www.britannica.com/topic/Freedom-of-the-Press-Act-of-1766

17. https://www.jn-news.com

18. (1966) International Covenant on Civil and Political Rights. The United Nations 999: 171. 